\title{
The Burden of Proof in Hugh Latimer's Sermons
}

\author{
SAAD EL-GABALAWY
}

Latimer is rightly described as "the finest stylist" among the early Reformers and the "greatest pulpit exponent of the colloquial style in the century." 1 The power of his eloquence lies mainly in the variety of arrangement, the absence of constraining formal structure, the use of racy and pungent speech idiom, the conversational tone, the richness and freedom of imagination, the employment of frequent homely exempla, and the subtle adoption of such rhetorical devices as exclamatio, apostrophe, interrogatio, ironia, and sarcasmus in his sermons.

Part of his effect, however, lies in the sacred orator's confirmatio, based on his use of logic and rhetoric for the purpose of persuasion. But it is important at the outset to stress the interrelations of logic and rhetoric as sister-disciplines in the Renaissance. The affinities of logical proofs with the old rhetorical aim of persuasion were apparent to all cultured people in Latimer's day. Contemporary psychology made men less definite about the line dividing "feeling" from "thinking" than the average person now is. It would, therefore, be inaccurate to erect a neat wall between rhetorical and logical functions in Latimer's homilies.

According to the principles of classical rhetoric, the means of persuasion can be divided into "proofs," "manners," and "emotions," which correspond to the three objectives of eloquence: to "teach," "delight," and "move" the audience. St. Augustine conceives of these, "docere, delectare et movere," as the major functions of preaching. ${ }^{2}$ In the medieval oratorical tradition, the proof (confirmatio or probatio) has generally a limited sense; the preacher must use it to confirm the division (divisio) of his theme; that is, to assert the orthodoxy of his interpretation of the text by establishing legitimate relationships between the parts of his division and the different authorities, biblical, patristic, or profane. This kind of proof, designed to justify the division, is adopted only once by Latimer in a homily ad clerum (IV, I, 35), ${ }^{3}$ where the initial partition leads to formal structure and development.

He usually raises different questions connected with the central 
theme, thus unfolding various aspects and multiplying the possibilities of meaning. The question quis corresponds to the arguments a persona about individuals. The question quid corresponds with arguments $a$ re pertinent to action. The question cur corresponds to the arguments $a$ causa, the questions $u b i$ and quando to the arguments $a$ loco and $a$ tempore. These are the questions frequently found in Latimer's sermons which provide the basic elements in his divisions: "But now to come to my matter again: Videte et cavete ab avaritia: 'See and beware of covetousness'; and I shall desire you to consider four things: Quis dicat; quid dicat; cui dicat; et quare dicat" (XIV, I, 256). "For the understanding of this text it shall be very needful to consider the circumstances going before. . Who spake these words: to whom they were spoken: upon what occasion; and afore whom?" (XV, I, 282). This device is obviously used for purposes of exploration and amplification, but it does not normally lead to well-defined formal divisions in the homilies, which are marked by looseness of structure and frequent digressions. It does, however, provide the framework for the preacher to present his arguments and support the central ideas through different kinds of proofs.

In general terms, the word "proof" in Latimer's sermons signifies the demonstration of the thesis, setting in motion two types of reasoning: the discursive and the analogical. He occasionally uses such dialectical procedures as deduction, induction, syllogism and enthymeme. For instance, induction, which proceeds from effect to cause, from consequence to principle, serves to elucidate a prophetic passage in Scripture:

Further, the time giveth it that Christ should come: for so it was prophesied of the good holy father and patriarch Jacob. When he blessed his sons, he said: "The sceptre shall not depart from Juda, and a law-giver from between his feet, until Schilo come: and unto him shall the gatherings of the people be." Now at that time, when our Saviour was come, the sceptre was taken from Juda: for all Jewry was under the dominion of the Romans, therefore Schilo must needs come.

(XXXIII, II, 75-6)

As for deduction, which draws the conclusion from something known or assumed, it occurs frequently in Latimer's homilies, as in Sermon XIX: "For except schools and universities be maintained, we shall have no preachers: when we have no preachers. . how shall we come to that blessed kingdom which we desire?" (I, 358). In terms of formal logic, this ty pe of reasoning is defined as a primo ad ultimum.

With regard to syllogism, a superior aspect of reasoning favoured by contemporary universities, it appears on rare occasions in Latimer's sermons and usually assumes a simple form: "I have forgotten my logic, but yet I can jumble at a syllogism, and make an argument of it, to 
prove it by. Covetousness is the root of all evil: rebellion is an evil; ergo, covetousness is the root of rebellion" (XIV, I, 247). Similarly, he argues in Sermon XXXV, "Nobody can give everlasting life save only God. Christ giveth everlasting life; ergo, he is very natural God" (II, 100). But Latimer often prefers the enthymeme, a syllogism in which one premise is unexpressed, because this type is more intelligible to the public and more convenient for the preacher under the pressure of the moment.

However, it is important to assert that these forms of argumentation are only rarely employed by Latimer. In his own words, cited above, he seems to have forgotten scholastic logic, presumably as a reaction against its abuses by medieval theologians. Occasionally he parodies formal logic in order to expose and denounce its errors, fallacies and absurdities. For purposes of ridicule, he accumulates false inductions in these modes of argumentation: since God can save men unconditionally, they have no need to hear the Word; because God is able to preserve things from fire, "I will go and set my house a-fire, and it shall be preserved..." (XXVIII, I, 528). The same kind of ludicrous induction is again sarcastically revealed in this reasoning: "Here was preaching against covetousness all the last year in Lent, and the next summer followed rebellion; ergo, preaching against covetousness was the cause of rebellion" (XIV, I, 250). Thus, Latimer's use of argument according to formal principles is infrequent and overtly satirical, which suggests his rejection of the lessons of logic taught by the schoolmen.

His methods of argumentation, preeminently based on common sense and close analysis of biblical texts, place him side by side with Renaissance humanists and with masters of medieval eloquence such as St. Gregory, Guillaume d'Auvergne, Jean de Galles, or Thomas Waleys. Like them, he concentrates on careful examination of the text in order to organize his proofs effectively, often explaining little points of doctrine carefully and stating the nuances of different notions precisely. Latimer always seems concerned with the lucidity essential to moral and spiritual teaching, leading his listeners step by step to the core of the subject under discussion.

Definition constitutes a fundamental aspect of his reasoning, which denotes the preacher's analytical spirit, especially in points of biblical translations and exegeses. Most of the orthodox logic handbooks in Latimer's age included sections on "definition," "division," and "method," which were cant terms in the educational system. ${ }^{4}$ In fact, every youth of parts found himself constrained to learn how to "define and divide" from scholarly and popular manuals. Defining can be by name, by difference from other things, by contrary, by circumlocution, by example, by want or defect, by praise or dispraise, by similitude, by etymology. 
In Latimer's sermons, similar ideas and adjacent conceptions, which might cause confusion in the minds of the audience, are meticulously defined in order to draw fine distinctions and indicate divergences. This is manifest, for example, in Sermon XXX, where Latimer defines the nature of sin, introducing a series of distinctions: "Now there be two manner of laws. There be general laws, pertaining to every man and woman, and there be special laws. ... But there be two manner of sins: there is a deadly sin and a venial sin; that is, sins that be pardonable, and sins that be not pardonable" (II, 6-7). Latimer then proceeds to divide and classify men in relation to the state of salvation, all the time involving his audience in the definition and exploration of the concepts. Throughout the homily he seems to be deliberately avoiding vague abstractions and theological niceties which cannot be easily grasped by the mind. Since naked ideas are often difficult to sustain imaginatively, Latimer usually attempts to define and distinguish them by concrete example and similitude for the sake of practical efficacy.

He frequently cites diverse translations of certain terms in order to eliminate any possibility of confusion or misconception, as in Sermon XIII: "The text is, Tunc cum venisset Jesus in villam, quae dicitur Gethsemani, 'Then when Jesus came'; some have in villam, some in agrum, some in praedium. But it is all one" (I, 217). Elsewhere, Latimer dwells at length on the verse, "dilectionem habueritis ad invicem," to define and distinguish the different meanings and connotations of the word "love" (XXIV, I, 448). He asserts that the Jews understood Christ well, since he spoke to them in their own "natural terms and tongue." Therefore, "it shall be necessary to expound [words], and compare them unto some like terms of our natural speech, that we in like manner may understand Christ as well as the Jews did" (I, I, 9). In his ardent desire to assimilate the Word fully, Latimer tends to explore various possibilities of meaning, by splitting words and ideas, instead of lumping them together. Like Lancelot Andrewes later in the century, he dissects and squeezes the letter in order to extract the last drop of sense, revealing the spirit in all its dimensions.

Not only does Latimer look into the language of his day for "natural terms" or idiomatic equivalents, he also tries to integrate biblical manners and morals into contemporary life. For the Bible to bear upon the current situations of his listeners, he transforms it into the words and practices of their daily life, so that his translations and interpretations suggest many semantic as well as affective equivalents. Thus, Gideon becomes "a duke, which God raised up to deliver the children of Israel from the Midianites. .." (III, I, 31). Potiphar in Genesis is portrayed as a "lieutenant of the Tower" in Egypt (XXI, I, 396). Nineve in the Old Testament is compared to London and Capernaum to "Bristow or 
Coventry" (XIV, I, 241; XXIX, I, 533). In his famous "Sermon of the Plow," Latimer identifies London with the city of Nebo, which Jeremiah condemned for its sins. The Last Judgement, the Sanhedrin and the Gehenna correspond to "the sessions of inquirance, the sessions of deliverance, and the execution day" (I, I, 12).

In his deep concern with the practical effect of the homilies, Latimer recurrently explains many Scriptural texts through social and ethical conceptions of the contemporary era. For instance, just as Moses forbade the people of Israel to eat flesh with blood, so Englishmen should not be allowed to eat raw meat, which "should engender in us a certain cruelness, so that at length one should eat another" (XXX, II, 14). Similarly, the males of Israel were ordered to come together three times a year in Jerusalem so that "they should learn to trust in God" as if "we Englishmen had commandment to come all to London, and leave our country, were it not to be feared that the country should be hurt either by the Scots or Frenchmen in our absence" (XXXVIII, II, 156).

Along the same line, Latimer conveys an exquisite interpretation of the episode of David taking a young wife in his old age, relating it to the moral and spiritual regeneration stimulated by the Reformation in England. Like many medieval painters, he can assimilate biblical antiquity, with all its strangeness and local colours, to the English environment and Occidental ways of life. The armoured knights and beautiful ladies who appear in some Renaissance scenes of the Nativity and the Crucifixion, are also the invisible heroes of many homilies by Latimer. In his profoundly religious age, the sacred is almost always accessible in terms of the present reality. For him and his contemporaries, all human activities are preeminently related to God, even in their profane manifestations. In fact, with their sharp awareness of His immanence, they conceive of all phenomena as an extended parable of religious and ethical truth.

There is, however, the odd moment when doctrinal, social, or moral bias leads Latimer to impose arbitrary interpretations on the biblical text. Commenting, for example, on the journey to Jerusalem when Christ was twelve years old, he goes far beyond the text in order to illustrate a point of dogma. Mary is shown in a state of anxiety and despair: "Alas, that ever I was born, that I should lose my son, whom I heard say should be the Saviour of the world! This Saviour is lost now through my negligence and slothfulness. What shall I do? Where shall I seek him?" (XXXVIII, II, 157). In his refutation of Roman Catholic dogma, Latimer fabricates this fanciful attitude in Mary, without tex tual evidence, to expound one of his favourite notions that she was not sinless.

The same distortion can be seen in his defence of the position which 
might be called social theodicy: the social order, given its inequalities of possession and opportunity, has been divinely ordained and established. Latimer's commentary on "Our Father, give us this day our daily bread," conveys a strange justification of inequality, revealing an unmistakable weakness of reasoning. For him, "it appeareth most manifestly" that the wealthy obtain their riches from God, not only through their own prayers, but also by means of "the poor man's prayer." "God made some rich and some poor: the poor he sendeth unto the rich to desire of him in God's name help and aid" (XXI, I, 399). On this basis, since the rich are indebted to the intercession of the poor, they should offer part of their earthly goods to their miserable neighbours, in a spirit of charity and compassion. As God's "officer" and "treasurer," a rich man should distribute some of his possessions according to his Lord's commandment.

Through this kind of logic, Latimer vehemently urges the poor not to rebel against the divine order. If they are homeless, Christ too had no house for His birth. If they lack shelter, there are "many mansions" in the "Father's house." While the starving masses are seething with revolt, Latimer acts as the exponent and propagandist of the established class system, making an apology for poverty and defending the status quo in unequivocal terms. It should be noted, however, that he echoes the traditional arguments used by many Christian thinkers to justify the social hierarchy based on ranks and degrees.

Another interesting example of Latimer's questionable proofs and explanations, intended to vindicate social injustice, can be found in Sermon XXVI, preached two or three years after Ket's Rebellion (Summer 1549). Obsessed by the danger of chaos, he adopts a highly misleading argument about the "poor in spirit." In fact, he twists the biblical text to commend those who "take poverty well, without grudging" and condemn the people who rebel against the divine will when "God sendeth poverty unto" them $(I, 478)$. He recurrently declares that each man has an assigned position and function on the chain of being, designed by the Godhead to keep the universe in a state of harmony. This line of reasoning, usually based on contemporary assumptions, shows that Latimer reflects the dominant spirit of his age. Although he seems to reject scholastic forms of discourse, he still accepts traditional postulates and regards them as self-evident without proof.

In some of his sermons the rhetoric lends an aura of brilliant deception to his exposition. At times he strains and squeezes a passage to express arbitrarily a point of dogma, hence his commentary occasionally looks like expolitio rather than expositio. We may apply to Latimer in this regard George Puttenham's description of the "gorgious," expolitio, 
with its "varietie of sentences all running vpon one point \& to one intent," its "masse of many figuratiue speaches, applied to the bewtifying of our tale or argument." 5 Latimer often relies on the polish and lustre of flores rhetorici to emphasize meanings and arguments which lack logical bases. Likewise, he sometimes handles the text in an artificial manner, raising futile objections only to dissipate them with easy wit and triumphantly using rhetorical decoration as sound proof.

The modern reader may get the impression that the arguments in Latimer's homilies lack subtlety and sophistication, that they reveal a darting rather than a logical mind, that there is no profound theology behind the rhetorical flourish, that the biblical texts are sometimes tortured and chewed laboriously to yield the commonplaces of a conservative mind, that the proclamations of common sense are adopted instead of rigorous and logical demonstration. This is, no doubt, due to the fact that analogical reasoning overshadows discursive argumentation in the sermons. Like many of his contemporaries, Latimer tends to state and establish the obvious, to include divine revelation within the ethical and intellectual perimeter of the age. The proofs he employs consist mainly in comparisons and similitudes rather than causes, in examples and citations rather than deductions. Instead of proving assumptions through severe thought, he tends to corroborate traditional ideas, preferring the security of truisms established by experience and authority.

Latimer usually cites his authorities in Latin, which he fluently blends with English in both sermons and letters alike. Following the example of medieval preachers, this champion of Scriptures in the vernacular does not quote biblical texts except in Latin, consistently translating each of his quotations into the native tongue. According to B. Schulze, Latimer seems to use Erasmus' New Testament rather than the Vulgate, depending in most cases on memory, which leads sometimes to inaccurate citations, making the identification of his source extremely difficult. ${ }^{6}$ It is not unreasonable in this respect to wonder if he himself reconstructs the Latin text, following the translations of Tyndale or Coverdale, which he appears to retain, more or less, intact in his memory. We should note here that Latimer, following the spirit of the 1536 Injunctions, recommends a daily reading of at least one chapter of the Bible "conferring the Latin and the English together" (II, 243). The use of Latin gives his exposition an erudite flavour, blends his intimacy with a sense of remoteness (remarkable in Christ's teaching), inspires awe in the hearts of the audience and strengthens the voice of authority in the sermons. Without any implied insinuation as to Latimer's basic sincerity and honesty, I would suggest that he resembles Chaucer's Pardoner in the use cf Latin to "saffron with [his] predicacioun/And for to stire hem to devocioun." 7 It may be pertinent here to mention that C.S. 
Lewis observes some affinities of his method with that of the Pardoner. ${ }^{8}$

The use of Latin and English versions side by side does not detract from the vigour and liveliness of Latimer's style:

He is called Clemens, "Gracious;" Misericors, "Merciful;" Justus, "Right-
eous;" Puniens iniquitatem, "A punisher of wickedness;" Verax, "True;",
Omnipotens, "Almighty;" Longanimis, "Long-suffering, patient," Fortis,
"Hardy;" Ignis consumens, "A consuming fire;" Rex omnis terrae, "the
king over the whole earth;" Judex, "A Judge," Salvator, "A Saviour."
These and such like are the names of God.

(XVIII, I, 345)

This convenient method of amplification enables the sacred orator to repeat the text, sowing the seed, as it were, twice. The Latin phrase serves to set the limits of the citation unequivocally, while at the same time the translation offers the possibility of expansion in order to interpret the authority according to the desired sense: "Also, this is a true sentence used of St. Augustine, Non remittetur peccatum, nisi restituatur ablatum; 'Robbery, falsehood, or otherwise ill-gotten goods, cannot be forgiven of God, except it be restored again" (XXI, I, 404-5).

A Latin quotation may lead to different nuances of translation in accordance with the preacher's aim and the sermon's context. Take, for instance, the proverb "Vexatio dat intellectum." In a sermon on human trials, it is rendered as "Vexation and trouble maketh us to know ourselves and teacheth us to leave sin and wickedness" (XXVI, I, 480). Then in a homily on education Latimer uses the same proverb to convey a sense appropriate for the central theme: "Correction giveth understanding" (XXVII, I, 501). This tendentious manipulation reveals his crafty use of authorities, not to prove, but to amplify his ideas. Latimer has a habit of expounding and developing motifs through successive citations linked together by his characteristic method of loose association. In many cases, if the first quotation confirms the thesis, the others may not be strictly relevant to the theme. Such a procedure of free and easy association probably creates the false impression of "proof" in the minds of his listeners. The process can be adequately described as the rhetoric of illusion.

The authorities introduced as proofs include the biblical texts, the writings of the Church Fathers, as well as some secular authors and proverbs. The biblical authority consists in citing the words of God, Father and Son. This could be a pronouncement by Christ or an exhortation by a prophet speaking in the name of God. At times the oracle assumes a literary figure, "prosopopoeia," recommended by rhetoricians for its power to "confirme and make [the] cause evident," so that it "is very profytable in perswading, chyding, complayning, praysing and 
pittying." 9 Latimer attempts, so to speak, to act out his meaning through this peculiarly vivid form of interplay between abstractions and concretions.

Thus, the words of the sermon are put into the respective mouths of God or Christ or the Virgin Mary or Satan. In Sermon IV, for example, God's wrath against His ministers is directly expressed: "As though he should say unto us; "All good men in all places complain of you, accuse your avarice, your exactions, your tyranny..."' (I, 38). There is the same direct address in Sermon VII: "As who should say, "O ye children of Israel, I know your nature right well, which is evil, and inclined unto all evils..."' (I, 89). Likewise, Christ complains,

I came down into this world and so took on me bitter passion for man's sake, by the merits whereof I intended to make unity and peace in mankind, to make man brother unto me, and so to expel the dominion of Satan, the devil....

In a flight of uninhibited fancy, without oratorical precaution, Latimer portrays Mary thinking aloud: "God hath rejected me, and therefore hath taken my son from me: I shall no more find him" (XXXVIII, II, 157).

Through this device, he intensifies the effect of his sermon by creating the impression of a present experience here and now. Even the events of the Passion are recreated by Latimer in all their dramatic intensity, so that they acquire the maximum immediacy. In some of his homilies he obliterates the historic distance by putting words into the mouth of the Crucified. The oratio of Christ is thus abstracted from the world of historic events to be vividly re-enacted in the heart of the present. Such a method can be paralleled in medieval literature, homiletical, liturgical, devotional and poetical. Latimer's technique in this matter has a marked affinity with the Complaint of Christ medieval poems, based on the Improperia of Good Friday. Perhaps one of the best examples of this mode of expression can be found in some fourteenth-century lyrics of Friar Herbert, designed primarily for pulpit use. ${ }^{10}$ The dramatic method survives in some sixteenth- and seventeenth-century sermons such as Daniel Heinsius' Passion homily in The Mirrour of Humilitie. ${ }^{11}$ There is no doubt that Latimer finds the direct voice of divine authority one of the most efficacious tools to kindle the imagination of the audience in the process of persuasion.

Apart from the imaginary speeches of prosopopoeia, his other citations, sacred or profane, are usually attributed to their authors. Generally quoted in Latin, they are presented in their complete form, directly and succinctly. In English, however, some of them are reduced to a quick summary or even a fleeting allusion. As might be expected, 
Latimer lays great emphasis on proofs derived from the works of Augustine, quoted seventy times in the extant sermons. The other authorities frequently cited include Chrysostom, Jerome, Origen, Hilarius, Denis, Nicholas, and Gregory I. Among the profane sources are Terence, Ovid, and Horace. As for Greek sources, they are hardly mentioned in the homilies, which confirms Latimer's statement, "ego non calleo Graece," in his final examination at Cambridge. ${ }^{12}$

More than patristic or classical material, the proverb lore serves to nourish Latimer's wisdom and provide him with effective proofs, lending a colloquial pungency to his sermons. Besides the fact that proverbs resemble the sayings of the Fathers to a great extent, they are sanctioned by the Proverbs of Solomon, which endow them with great authority. Like the rest of Latimer's citations, most of them are introduced in Latin: "Qui vadit plane, vadit sane"; "Senex bis puer"; "Felix quem faciunt aliena pericula cautum"; "Simile gaudet simili" (I, 89, 113, 114, $117,158)$. Latimer also adopts some native common sayings such as "An evil crow, an evil egg"; "Young saints, old devils"; "the more wicked, the more fortunate"; "Say the truth and shame the devil" (I, 42, 431, $280,506)$. Occasionally the English version and the Latin equivalent appear side by side: "it would be said to me, that it is an evil bird that defiles his own nest; and, nemo laeditur nisi a seipso, there is no man hurt but of his own self"' $(I, 200)$. Further, the vogue of the proverb lore inspires Latimer with proper apothegms: "I will trouble you no longer. It is better a little well perceived and borne away, than a great deal heard and left behind" (I, 352).

Proverbs are among the figures chiefly praised by rhetoricians for their special power to imprint ideas on the mind. Because of their effectiveness, Latimer employs them as a useful means of illustration and persuasion. In this respect, he has behind him a long line of medieval preachers in Latin and in the vernacular. Among the most relevant examples are the English version of the Gesta Romanorum and John Mirk's homilies, ${ }^{13}$ which abound in current popular sayings, derived from different sources. In Latimer's age there are many other great exponents of the mode, particularly John Bridges who is remarkable for his generous use of proverbs. ${ }^{14}$ Professor W.W. Skeat maintains that "one of the ways in which proverbs were formally popularized was by their use in sermons delivered in the vernacular." 15

At times, in his use of proverbs as proofs, Latimer blends his authorities, biblical, patristic or profane, without any apparent preference:

But the quiet life is in a mediocrity. Mediocres optime vivunt: "They that are in a mean do live best." And there is a proverb which I read many years ago, Dimidium plus toto; "The half sometimes more than the whole." I remember here a saying of Solomon, and his example: Conservavi mihi 
argentum et aurum, I gathered silver and gold together," saith he. . .

(XIV, I, 277-78)

The wisdom of Solomon is here combined with that of common people to confirm the preacher's thesis. Latimer's "concoction" reveals that he is much more tolerant than his Puritan successors, who take great pains to unequivocally draw a sharp line of division between sacred and profane authorities. In his homilies, the accumulation of diverse sources, like the use of numerous citations, creates an abundance of verbal and amplificative material which seems quite convincing by virtue of its volume, if not by its intellectual rigour.

The ruminating and rambling narrative tendency in Latimer is more perceptible in another category of proofs, the exemplum, which usually consists of a short narrative designed to serve as proof and at the same time to enhance amplification and augment ornamentation. The logical duty of an extended exemplum in his sermons is frequently to argue by analogy. Concrete cases are introduced as arguments from the special to the general, from the particular to the universal. Like the citation of authorities, the use of exempla is intended not as a mere expository flourish, but as the embodiment of concepts, which has logical validity, vertu or strength.

Largely employed in medieval literature, the exemplum became an integral, sometimes essential, part of the homiletical tradition. According to Ten Brink, the "preachers, and especially the mendicant friars, had long been in the habit of making use of Aesopian fables and other tales in the pulpit." 16 These didactic and edifying anecdotes are often derived from sacred or profane history, the lives of saints, legends or bestiaries, jests and satirical tales, adapted fabliaux and abridged romances. Since the thirteenth century, homilists, chroniclers, and moralists had grasped the dramatic and oratorical value of anecdotes, using them abundantly to prove their assertions and arouse the interest of the public.

The tendency of pulpiteers to become narrators reveals itself in the multiple exempla which abound in Latimer's sermons. But we should note that in his narratives he normally uses plausible and realistic illustrations rather than the legendary incidents prevalent in the later Middle Ages. He often draws his material from biblical parables, ecclesiastical history, hagiography, or secular chronicles. In Sermon XXIX, he admonishes the audience "not to be too hasty with dead corpses," recounting a tale by St. Augustine about a man who spent seven days in a trance before speaking again and coming back to life (I, 539). Similarly, Latimer narrates the history of a French king who travelled towards the Holy Land (VII, I, 95), or relates stories about St. Anthony and St. Bernard (I, 392, 519). 


\section{4 / Renaissance and Reformation}

There are also pious or moral exempla, as in the tale of the "popish woman," who found Christ just before the day of her execution (XI, I, 180). Further, Latimer sometimes adopts profane anecdotes which include allusions to manners, customs and experiences of real life. Like medieval friars, he goes ever to current life for homely analogies, deriving his verbal illustrations from everyday things as seen by his shrewd eyes. We may also note his occasional use of prosopopoeias, fabliaux, personal reminiscences, or hypothetical examples to demonstrate various propositions. Most engaging are the lively anecdotal references to his early years on the farm. Some of his affirmations include testimonies and confessions of reliable witnesses, which he finds persuasive and convincing. The pastoral ministry places Latimer in a privileged position to employ arguments from testimony, selecting narrative evidence from his vast spiritual and worldly experience. Again and again he cites the words of men condemned to death as the ultimate evidence to support his thesis. Such examples are naturally designed to demonstrate the sound bases of certain assertions, assuming a unique position as proofs in the sermons.

To prove the affirmation that it is better to go to church out of curiosity than to stay idly at home, Latimer cites the example of an impious woman who attends the church service regularly for repose and sleep. The recollection of this woman evokes an unpredictable association: the analogous example of St. Augustine, who "was very desirous to hear St. Ambrose, not for any love he had to the doctrine he taught, but to hear his eloquence....Well, before he departed, St. Ambrose caught him on his hook, and converted him" (XII, I, 201). In the process of corroborating the initial affirmation, Latimer expounds a new moral about the unintentional conversion of Augustine through his exquisite taste for rhetoric. This technique of association can be safely regarded as a typical procedure of Latimer.

However, it is clear that he never loses sight of his major objective of moral edification, while attempting to amuse and please his audiences. The great number of exempla, as well as the high proportion of biblical stories and personal anecdotes in the sermons, clearly indicate the temperament of the narrator in Latimer. Besides, his innate talent reveals itself primarily in the association of ideas and in the remarkable ability to perceive relations between disparate experiences. This mechanism inevitably contributes to the amplification and confirmation of his themes through a series of identical or similar examples, narrative or demonstrative.

But while the demonstration in narrative form can become an effective tool of persuasion, there is always the danger of the preacher losing sight of his point of departure, so that he gradually takes a new direction, 
independent of the main subject. This is clear in Sermon XIV, where Latimer illustrates the theme of covetousness through the story of the two brothers in Luke 12:13. He proceeds to talk about mutual understanding between brothers; this point evokes a lengthy discourse on dissensions among Christian kingdoms, which leads arbitrarily to the example of the crafty merchant who plays one brother against the other to destroy them both. The narrator finally resumes the account of Luke and Christ's response, but he still finds it important to comment on the interrogative form in Jesus' reply and to cite another example of an interrogative answer in the parable of the good Samaritan, followed by a story about the bishop of Exeter. At length it is time to go back to the subject: "But to the purpose of Christ's question, 'Who made a judge between you?'” (I, 272). Latimer's affinities with the entertaining preachers of the fourteenth century do not appear more clearly than in this example of digression, which dislocates the plan of discourse.

Sometimes the illustration has very superficial relevance to the subject, as when he narrates the tale of Harpagus, who unwittingly ate his son, to demonstrate the central doctrine of Christianity that God "offereth his only Son to be eaten, and his blood to be drunken" (XXV, I, 457-58). In other cases, the examples seem totally unrelated to the central theme, but the narrative digressions are unconvincingly and weakly justified by the homilist: "I told you in my last sermon of ministers, of the king's people; and had occasion to shew you how few noblemen were good preachers; and I left out an history then, which I will now tell you" (VIII, I, 118).

This disposition to use numerous and varied exempla endows Latimer's sermons with an air of ease, familiarity and intimacy, which again calls to mind the method of Chaucer's Pardoner. One anecdote is loosely linked to the other, just as the orator's stream of thought, eluding the constraint of any static form, flows with absolute freedom through unexpected associations. The liberty of the imagination makes of a Latimer homily a kind of informal chat at once calm and capricious, which reminds us that the Latin word "sermo" signified a conversation or mutual talk. ${ }^{17}$ Because of its informal nature, his address is not merely an oration; it retains something of the original sermo. By virtue of its variety and original intuitions, it rarely loses the attention of the listeners, serving effectively to sway them. Besides, the exempla contain a highly dramatic element, so that each moral or conclusion becomes the dénouement of a little play, which sustains interest and suspense through the action and dialogue of its protagonists. That is why of all the categories of proofs, the exemplum appears to be Latimer's favourite one. Not only does it allow him to reveal his innate talent for association, amplification, and drama, but it also provides the proofs best adapted 


\section{6 / Renaissance and Reformation}

and appropriate to the needs, tastes, and interests of his listeners.

The needs of the audience and the central theme of the homily lead to a different kind of proof in Latimer's "Sermon of the Plow." Robert L. Kelly has recently observed that in this instance, "it would not be rhetorically strategic to rely too heavily on traditional authority," taking into consideration the fact that the substance of the sermon is clearly a defence of the reform measures. Hence, Latimer seems to use Piers Plowman as an "idealized persona," representing a tradition both ancient and orthodox. Through the hallowed image of Piers, who speaks with the authority of the Bible, the preacher voices the religious ideals of England in the era of reform. In other words, Latimer leads his audience to a realization that he shares Piers' attributes and speaks with his authority. Piers becomes the guise in which the homilist addresses his countrymen as the prophet of the New Jerusalem. ${ }^{18}$

The central motif of husbandry in the sermon appears organically related to this conception, suggesting to the listeners the notion of Latimer himself as the ideal preacher-plowman, especially in his condemnation of peers and superiors in high places. The homily's immediate argumentative purpose lies in Latimer's use of Piers' orthodox tradition to sanction reform and non-conformity. Such a tradition is especially effective, given his need of an accepted external authority that represents orthodoxy and reform simultaneously.

In the light of this study, it is clear that Latimer's arguments usually come to bear upon contemporary life. The unrighteous judge, the poor widow, the covetous landlord, or the hypocritical clergyman does not remain confined within the pages of the sacred text, but is made relevant to the English reality. The preacher's ethical preoccupation exerts a remarkable influence on his choice of logical and rhetorical tools to demonstrate and prove various theses in the sermons. Avoiding dialectical argumentation as far as possible, Latimer seems keenly aware that moral and spiritual lessons cannot bear fruit unless they are retained by the memory. That is why he relies mainly on authoritative citations, proverbs, and exempla, chosen on the ground of perceived relations which are easy to grasp and almost universally apprehensible.

In handling such proofs, he reflects a technique of evangelical preaching, developed through contact with men and familiarity with human reflexes. Instead of awakening the intellect through discursive reasoning, he appeals to the imagination in order to touch the heart and, in the words of Augustine, "sway the mind so as to subdue the will." 19 This is based on the assumption that people, especially unsophisticated audiences, are generally more emotional than rational, more responsive to evocative imagery than to dry logic. In his approach, therefore, Latimer employs all the seduction of his talent as a skilful narrator, his 
natural gift to associate themes and examples, developing and linking them together through some kind of imaginary logic.

\author{
University of Calgary
}

\title{
Notes
}

1 J.W. Blench, Preaching in England in the Late Fifteenth and Sixteenth Centuries (New York, 1964), p. 142.

2 On Christian Doctrine, trans. J.F. Shaw, in Vol. IX of The Works of Aurelius Augustine, ed. Marcus Dods (London, 1873), p. 141.

3 All citations from Latimer's sermons refer to The Works of Hugh Latimer, ed. G.E. Corrie, 2 vols., Parker Society (Cambridge, 1844-45). For the sake of convenience, I consistently insert sermon, volume and page references in parentheses.

4 The sixteenth-century approach to the sister-disciplines of logic and rhetoric can be exemplified by Leonard Cox, The arte or crafte of rhethoryke (London, 1524); Richard Sherry, $A$ treatise of schemes $\&$ tropes (London, 1550), A treatise of the figures of grammer and rhetorike (London, 1555); Thomas Wilson, The rule of reason, conteinyng the art of logique (London, 1551), The arte of rhetorique (London, 1553); Richard Rainolde, $A$ booke called the foundacion of rhetorike (London, 1563); Ralph Lever, The arte of reason, rightly termed, witcraft (London, 1573); Peter Ramus, The logike of. . .P. Ramus (London, 1574); Dudley Fenner, The artes of logike and rethorike (London, 1584); Abraham Fraunce, The arcadian rhetorike (London, 1588), The lawiers logike (London, 1588); Thomas Blundeville, The arte of logicke (London, 1599). For modern treatments of the subject, see, for instance, A.F. Leach, English Schools at the Reformation (London, 1896); F. Watson, English Grammar Schools to 1660: Their Curriculum and Practice (Cambridge, 1908); D.L. Clark, Rhetoric and Poetry in the Renaissance (New York, 1922); W.F. Mitchell, English Pulpit Oratory from Andrewes to Tillotson (London, 1932); Hardin Craig, The Enchanted Glass (New York, 1936), chap. vi; W.G. Crane, Wit and Rhetoric in the Renaissance (New York, 1937); C.S. Baldwin, Renaissance Literary Theory and Practice (New York, 1939); T.W. Baldwin, William Shakespere's 'Small Latine \& Lesse Greeke' (Urbana, 1944); Rosemond Tuve, Elizabethan and Metaphysical Imagery (Chicago, 1947), esp. Part II; W.S. Howell, Logic and Rhetoric in England 1500-1700 (Princeton, 1956); M.L. Clark, Classical Education in Britain 1500-1900 (Cambridge, 1959); K. Charlton, Education in Renaissance England (London, 1965).

5 The Arte of English Poesie, ed. Gladys Willcock and Alice Walker (Cambridge, 1936), Ch. XX, p. 247.

6 Latimers Kanzelberedsamkeit (Münster, 1924), p. 4.

7 "The Pardoner's Prologue," 11. 345-46, in The Complete Works of Geoffrey Chaucer, ed. F.N. Robinson (Cambridge, Mass., 1933).

8 English Literature in the Sixteenth Century Excluding Drama (Oxford, 1973 reprint), p. 194. 9 Henry Peacham, The Garden of Eloquence (London, 1577), Sig. 04 V .

10 See Religious Lyrics of the XIVth Century, ed. Carleton Brown (Oxford, 1924), "Introduction," p. xiv.

11 The Mirrour of Humilitie, trans. I. Harmer (London, 1618), STC 13039.

12 Quoted by C.S. Lewis, op. cit., p. 193.

13 The Early English Versions of the "Gesta Romanorum," ed. S.J. Herrtage, EETS, E.S. 33, 3rd reprint (London, 1932); Mirk's Festial: A Collection of Homilies, ed. Theodor Erbe, EETS, E.S. 96 (London, 1905). 


\section{$118 /$ Renaissance and Reformation}

14 See, e.g., A Sermon, preached at Paules Crosse (London, 1571).

15 Early English Proverbs (Oxford, 1910), p. vii.

16 History of English Literature, trans. H.M. Kennedy (London, 1887-96), 1, 264.

17 See J.A. Broadus, $A$ Treatise on the Preparation and Delivery of Sermons, 2nd ed. (London, 1898), p. 15.

18 “Hugh Latimer as Piers Plowman," SEL, Vol. XVII, No. 1 (Winter 1977), pp. 13-26.

19 Op. cit., p. 141. 